\title{
Persistence of Anti-SARS-CoV-2 Antibodies Depends on the Analytical Kit: A Report for Up to 10 Months after Infection
}

\author{
Julien Favresse ${ }^{1,2, *}$, Christine Eucher ${ }^{1}$, Marc Elsen ${ }^{1}$, Constant Gillot ${ }^{2} \oplus$, Sandrine Van Eeckhoudt ${ }^{3}$, \\ Jean-Michel Dogné ${ }^{2}$ and Jonathan Douxfils ${ }^{2,4}$ (1) \\ 1 Department of Laboratory Medicine, Clinique St-Luc Bouge, 5004 Namur, Belgium; \\ christine.eucher@slbo.be (C.E.); marc.elsen@slbo.be (M.E.) \\ 2 Department of Pharmacy, Namur Research Institute for Life Sciences, University of Namur, \\ 5000 Namur, Belgium; constant.gillot@unamur.be (C.G.); jean-michel.dogne@unamur.be (J.-M.D.); \\ jonathan.douxfils@unamur.be (J.D.) \\ 3 Department of Internal Medicine, Clinique St-Luc Bouge, 5004 Namur, Belgium; \\ sandrine.vaneeckhoudt@slbo.be \\ 4 Qualiblood s.a., 5000 Namur, Belgium \\ * Correspondence: j.favresse@labstluc.be
}

check for updates

Citation: Favresse, J.; Eucher, C.; Elsen, M.; Gillot, C.; Van Eeckhoudt, S.; Dogné, J.-M.; Douxfils, J. Persistence of Anti-SARS-CoV-2 Antibodies Depends on the Analytical Kit: A Report for Up to 10 Months after Infection.

Microorganisms 2021, 9, 556. https:// doi.org/10.3390/microorganisms9030556

Academic Editor: Oliver Schildgen

Received: 7 February 2021

Accepted: 5 March 2021

Published: 8 March 2021

Publisher's Note: MDPI stays neutral with regard to jurisdictional claims in published maps and institutional affiliations.

Copyright: (C) 2021 by the authors. Licensee MDPI, Basel, Switzerland. This article is an open access article distributed under the terms and conditions of the Creative Commons Attribution (CC BY) license (https:/ / creativecommons.org/licenses/by/ $4.0 /)$.

\begin{abstract}
Several studies have described the long-term kinetics of anti-SARS-CoV-2 antibodies but long-term follow-up data, i.e., $>6$ months, are still sparse. Additionally, the literature is inconsistent regarding the waning effect of the serological response. The aim of this study was to explore the temporal dynamic changes of the immune response after SARS-CoV-2 infection in hospitalized and non-hospitalized symptomatic patients over a period of 10 months. Six different analytical kits for SARS-CoV-2 antibody detection were used. Positivity rates, inter-assay agreement and kinetic models were determined. A high inter-individual and an inter-methodology variability was observed. Assays targeting total antibodies presented higher positivity rates and reached the highest positivity rates sooner compared with assays directed against IgG. The inter-assay agreement was also higher between these assays. The stratification by disease severity showed a much-elevated serological response in hospitalized versus non-hospitalized patients in all assays. In this 10-month follow-up study, serological assays showed a clinically significant difference to detect past SARS-CoV-2 infection with total antibody assays presenting the highest positivity rates. The waning effect reported in several studies should be interpreted with caution because it could depend on the assay considered.
\end{abstract}

Keywords: COVID-19; SARS-CoV-2; antibody; kinetics; long-term; waning effect

\section{Introduction}

Currently, the revelation of SARS-CoV-2 RNA through a real-time reverse transcription polymerase chain reaction (RT-PCR) from nasopharyngeal swab samples is considered to be the gold standard method for the diagnosis of acute SARS-CoV-2 infection. Less invasive salivary samples have also been reported as an alternative to nasopharyngeal swab samples [1]. The targeted genes for RT-PCR detection may include a combination of $N, E, R d R p$, orf1 $a$ and orf1b genes.

The detection of anti-SARS-CoV-2 antibodies serves as an adjunct to molecular testing for the diagnosis of COVID-19 especially in patients who present late with a low viral load. Serological testing has been successfully used to evaluate seroprevalence, to identify convalescent plasma donors, to monitor herd immunity and for risk predictions [2-4] Antibody assessment and monitoring are also likely to play a key role in the context of the global vaccination strategy [5].

Compared with commercial immunoassays, only neutralization activity assays reliably measure the actual protective immunity of antibodies [6]. However, neutralization activity assays are only reserved for specialized laboratories and require a high workload, 
skillful operators, expensive installations, crucial biosafety measures and have, to date, a low throughput. Therefore, the use of fully automated immunoassays that have a welldemonstrated correlation with neutralization activity should be considered in the routine clinical setting [5].

Current serological assays use different SARS-CoV-2 antigen targets (i.e., nucleocapsid protein (NCP), spike proteins (S) and the receptor-binding domain (RBD)) and formats (i.e., immunoglobulin G (IgG), IgA, IgM or total antibodies). Most assays possess a unique target but multiplex assays have also been developed and validated $[7,8]$. The NCP participates in RNA packages and the release of virus particles while the transmembrane spike glycoprotein comprises two functional subunits responsible for binding to the host cell receptor (N-terminal S1 subunit) and for the fusion of the viral and cellular membranes (C-terminal S2 subunit) [9]. The RBD is located at the C-terminal region of the S1 subunit [10]. The RBD interacts with human cells that express angiotensin-converting enzyme 2 (ACE2) and induces the entry of the virus.

The antibody response to SARS-CoV-2 infection has been shown to be directed against multiple antigens of the virus including different epitopes of the spike protein. Antibodies targeting the RBD in the C-terminal region of the S1 subunit have been considered to be neutralizing [11]. Other antibodies target the NCP or non-structural proteins and their detection can be used as markers of recent infection $[7,8]$.

Reports evaluating antibody persistence inconsistently mention a waning effect of the serological response [12-14]. Based on these observations, a few authors have claimed that cross-sectional seroprevalence studies to evaluate population immunity may underestimate rates of prior infections [12]. A recent report also suggests that changing the vaccine policy to give to previously infected individuals only one dose of the vaccine would not negatively impact their antibody response and may consequently free up many vaccine doses [15]. Therefore, the divergent opinions regarding antibody persistence warrant further investigations to ensure an accurate and reliable evaluation of the serological status of each individual because, depending on the vaccinal strategy that will be applied in the coming weeks, this could represent the saving of up to 100 million vaccine doses worldwide [16].

The aim of this study was therefore to explore the temporal dynamic changes of immune response after SARS-CoV-2 infection in hospitalized and non-hospitalized symptomatic patients for a period of up to 10 months using different analytical kits for SARSCoV-2 antibody detection. This will permit the investigation of, and provide more insight into, the understanding of this possible waning effect.

\section{Materials and Methods}

The study protocol was in accordance with the Declaration of Helsinki and was approved by the Medical Ethical Committee of Saint-Luc (Bouge, Belgium; approval number B0392020000005).

\subsection{Patients and Samples Collection}

This study was conducted at the clinical biology laboratory of the Clinique SaintLuc (Bouge, Namur, Belgium). A total of 201 samples from 84 patients with a confirmed SARS-CoV-2 RT-PCR were retrospectively included from 26 March 2020 to 6 January 2021. Information on the days since the onset of symptoms was collected from medical records. When data about symptoms were not available $(n=15)$, the day of diagnosis (i.e., RT-PCR result) was used instead. Different time intervals were also created to calculate the rate of positive samples (i.e., 0-15, 15-40, 41-100, 101-150, 151-200, 201-235 and 236-300 days). Blood samples were collected into serum-gel tubes (BD SST II Advance ${ }^{\circledR}$, Becton Dickinson, NJ, USA) according to the standardized operating procedure and manufacturer recommendations. Samples were centrifuged for $10 \mathrm{~min}$ at $1740 \times g$ on a Sigma 3-16KL centrifuge. Sera were stored in the laboratory serum biobank at $-20{ }^{\circ} \mathrm{C}$ from the collection 
date. Frozen samples were thawed for $1 \mathrm{~h}$ at room temperature on the day of the analysis. Re-thawed samples were vortexed before the analysis.

\subsection{Analytical Procedures}

Six commercial immunoassays were used to evaluate the long-term kinetics of antibodies. The characteristics of these assays are presented in Table 1. Each patient's sample was analyzed on the six different assays. The results rendered below the limit of quantification (LOQ) of the assay were rounded to the LOQ of each assay to allow quantitative calculations and data processing.

Table 1. Characteristics of the six assays used in this study.

\begin{tabular}{|c|c|c|c|c|c|c|c|}
\hline No & Manufacturer & Platform & Technology & Antigenic target & Antibody format & Positivity cut-off & Units \\
\hline 1 & Roche Diagnostics & Cobas 801 & ECLIA & RBD & Total antibodies & $\geq 0.8$ & $\mathrm{U} / \mathrm{mL}$ \\
\hline 2 & Roche Diagnostics & Cobas 801 & ECLIA & $\mathrm{NCP}$ & Total antibodies & $>1.0$ & COI \\
\hline 3 & DiaSorin & Liaison XL & CLIA & $\mathrm{S} 1+\mathrm{S} 2$ & IgG antibodies & $\geq 15$ & $\mathrm{AU} / \mathrm{mL}$ \\
\hline 4 & Ortho Clinical Diagnostics & VITROS 3600 & CLIA & S1 & IgG antibodies & $\geq 1.0$ & $\mathrm{~S} / \mathrm{C}$ \\
\hline 5 & Ortho Clinical Diagnostics & VITROS 3600 & CLIA & S1 & Total antibodies & $\geq 1.0$ & $\mathrm{~S} / \mathrm{C}$ \\
\hline 6 & Thermo Fisher Scientific & Phadia 250 & ELiA & S1 & IgG antibodies & $>10$ & $\mathrm{U} / \mathrm{mL}$ \\
\hline
\end{tabular}

The RT-PCR for SARS-CoV-2 determination in respiratory samples (nasopharyngeal swab samples) was performed on the LightCycler ${ }^{\circledR} 480$ Instrument II (Roche Diagnostics ${ }^{\circledR}$ ) using the LightMix ${ }^{\circledR}$ Modular SARS-CoV E-gene set.

\subsection{Statistical Analyses}

Descriptive statistics were used to analyze the data. A Mann-Whitney test was used to compare the different groups. The positivity rates were calculated as the proportion of SARS-CoV-2 positive samples by serological tests initially categorized as positive by the RT-PCR. A non-linear regression model with log-transformed data was used to compute the antibody kinetics since symptom onset (or diagnosis) using the following equation:

$$
\begin{gathered}
{\left[\frac{\text { AUC } * \text { disappearance rate } * \text { appearance rate }}{\text { appearance rate }- \text { disappearance rate }}\right]} \\
*[\operatorname{Exp}(- \text { disappearance rate } * \text { days since symptom onset })-\operatorname{Exp}(- \text { appearance rate } \\
* \text { days since symptom onset })]
\end{gathered}
$$

A survival analysis was also performed to estimate the cumulative probability of positive samples since symptom onset (or diagnosis) using a log-rank Mantel-Cox test comparison. Mantel-Haenszel hazard ratios were computed for between test comparison. Inter-rate agreements, i.e., agreement and Cohen's kappa, and correlation studies were also determined. A $p$ value $<0.05$ was used as a significance level. Data analysis was performed using GraphPad Prism ${ }^{\circledR}$ (version 9.0.1, California, CA, USA), MedCalc ${ }^{\circledR}$ (version 14.8.1, Ostend, Belgium) and JMP ${ }^{\circledR}$ software (version 15.2.1, Cary, NC, USA).

\section{Results}

\subsection{Population Characteristics}

Among the 84 individuals, 44 were females (median age $=46$ years; min-max: $24-95$ years) and 40 were males (median age $=61$ years; min-max: $24-88$ years). Multiple sequential sera were available for 55 patients and 17 required hospitalization (i.e., categorized as severe patients). Hospitalized patients were elder (median age $=74$ years) compared with non-hospitalized patients (median age $=46$ years; $p$ value $=0.0007$ ). The 
median time between the symptom onset and the RT-PCR was three days (interquartile range (IQR): $1-8$ days).

\subsection{Kinetics of Positivity Rates}

In samples collected early since symptom onset (i.e., $<15$ days), positivity rates were low. The Roche NCP total antibody assay had the highest positivity rate in this time period (i.e., 69.2\%) while the DiaSorin S1 + S2 IgG and the Phadia S1 IgG assays showed the lowest positivity rates (i.e., $38.5 \%$ ). At the second time point, the highest positivity rates were observed for the Roche NCP and the Ortho S1 total assays (i.e., $96.3 \%$ and $100 \%$, respectively). A gradual increase in positivity rates toward a plateau was observed for both the Roche RBD and the Ortho S1 total assays with the latter reaching the plateau earlier than the Roche RBD total antibody assay. The highest positivity rates for the other assays were observed at the fourth time point (i.e., for the Phadia S1 IgG and the Ortho S1 IgG assays) and at the fifth time point (i.e., for the Roche NCP total antibody and the DiaSorin S1 + S2 IgG assays) (Table 2). Overall, the total assays presented higher positivity rates and reached their highest positivity rates sooner compared with IgG assays.

Table 2. Positivity rates according to different time points using six different assays. * represents maximal positivity rates observed. DSO = days since symptom onset.

\begin{tabular}{|c|c|c|c|c|c|c|c|c|}
\hline & DSO (or diagnosis) & 0-15 & $16-40$ & 41-100 & $101-150$ & $151-200$ & 201-235 & $236-300$ \\
\hline & Time point no. & 1 & 2 & 3 & 4 & 5 & 6 & 7 \\
\hline & $\mathbf{n}$ & 13 & 27 & 29 & 33 & 35 & 29 & 35 \\
\hline \multirow{3}{*}{$\begin{array}{l}\text { Roche RBD total } \mathrm{Ab} \\
(\mathrm{U} / \mathrm{mL})\end{array}$} & Median & 3.7 & 16.9 & 127 & 169 & 254 & 165 & 295 \\
\hline & Interquartile range & $0.4-110$ & $2.4-170$ & $24.6-411$ & $68.9-429$ & $84.1-591$ & $64.4-687$ & $87.6-541$ \\
\hline & Positivity rate (\%) & 61.5 & 77.8 & $96.6^{*}$ & $100^{*}$ & $100^{*}$ & $96.6^{*}$ & $100^{*}$ \\
\hline \multirow{3}{*}{$\begin{array}{l}\text { Roche NCP total Ab } \\
\text { (COI) }\end{array}$} & Median & 6.4 & 19.1 & 49.6 & 63.9 & 63.9 & 45.3 & 28.9 \\
\hline & Interquartile range & $0.1-26.4$ & $6.0-29.8$ & $14.5-84.6$ & $34.9-114$ & $20.6-126$ & $13.9-74.0$ & $11.4-66.0$ \\
\hline & Positivity rate (\%) & 69.2 & 96.3 & 93.1 & 97.0 & $100^{*}$ & 93.1 & 94.3 \\
\hline \multirow{3}{*}{$\begin{array}{l}\text { DiaSorin S1+S2 IgG } \\
(\mathrm{AU} / \mathrm{mL})\end{array}$} & Median & 5.4 & 36.6 & 64.2 & 58.6 & 75.5 & 64.2 & 66.7 \\
\hline & Interquartile range & $3.8-78.5$ & $11.0-99.1$ & $21.8-161$ & $34.2-120$ & $36.1-104$ & $24.0-123$ & 23.6-101 \\
\hline & Positivity rate (\%) & 38.5 & 70.4 & 82.8 & 90.9 & $97.1^{*}$ & 86.2 & 91.4 \\
\hline \multirow{3}{*}{$\begin{array}{l}\text { Ortho S1 IgG } \\
(\mathrm{S} / \mathrm{C})\end{array}$} & Median & 0.2 & 6.8 & 9.6 & 8.5 & 9.9 & 6.0 & 7.6 \\
\hline & Interquartile range & $0.01-11.6$ & $2.8-13.9$ & $3.1-14.7$ & $5.6-13.3$ & $3.8-12.9$ & $2.6-12.6$ & $2.1-12.2$ \\
\hline & Positivity rate (\%) & 46.2 & 77.8 & 79.3 & $97.0^{*}$ & 94.3 & 86.2 & 94.3 \\
\hline \multirow{3}{*}{$\begin{array}{c}\text { Ortho S1 total Ab } \\
\text { (S/C) }\end{array}$} & Median & 18.9 & 60.1 & 138 & 228 & 308 & 219 & 341 \\
\hline & Interquartile range & $0.18-113$ & $10.9-164$ & $24.8-339$ & $115-457$ & $130-500$ & $111-469$ & $150-515$ \\
\hline & Positivity rate (\%) & 61.4 & $100^{*}$ & $96.6^{*}$ & $100^{*}$ & $100^{*}$ & $96.6^{*}$ & $100^{*}$ \\
\hline \multirow{3}{*}{$\begin{array}{l}\text { Phadia S1 IgG } \\
\quad(\mathrm{U} / \mathrm{mL})\end{array}$} & Median & 3.8 & 20.0 & 31.0 & 25.0 & 21.0 & 15.0 & 15.0 \\
\hline & Interquartile range & $0.7-148$ & $11.0-152$ & $10.5-134$ & $12.0-64.0$ & $5.3-45.0$ & $4.9-37.5$ & $4.7-28.0$ \\
\hline & Positivity rate (\%) & 38.5 & 77.8 & 75.9 & $81.8^{*}$ & 68.6 & 55.2 & 60.0 \\
\hline
\end{tabular}

\subsection{Kinetic Models of Serological Response}

Figure 1 represents the level of antibody response by days after symptom onset according to severity. Depending on the assay and/or the population considered, a rapid increase in antibody titers was observed followed by a plateau phase or a decrease phase. 
After 300 days, hospitalized patients had overall a higher maximal response peak and a more persistent antibody response (e.g., the Roche NCP total antibody and the DiaSorin S1 + S2 IgG assays).
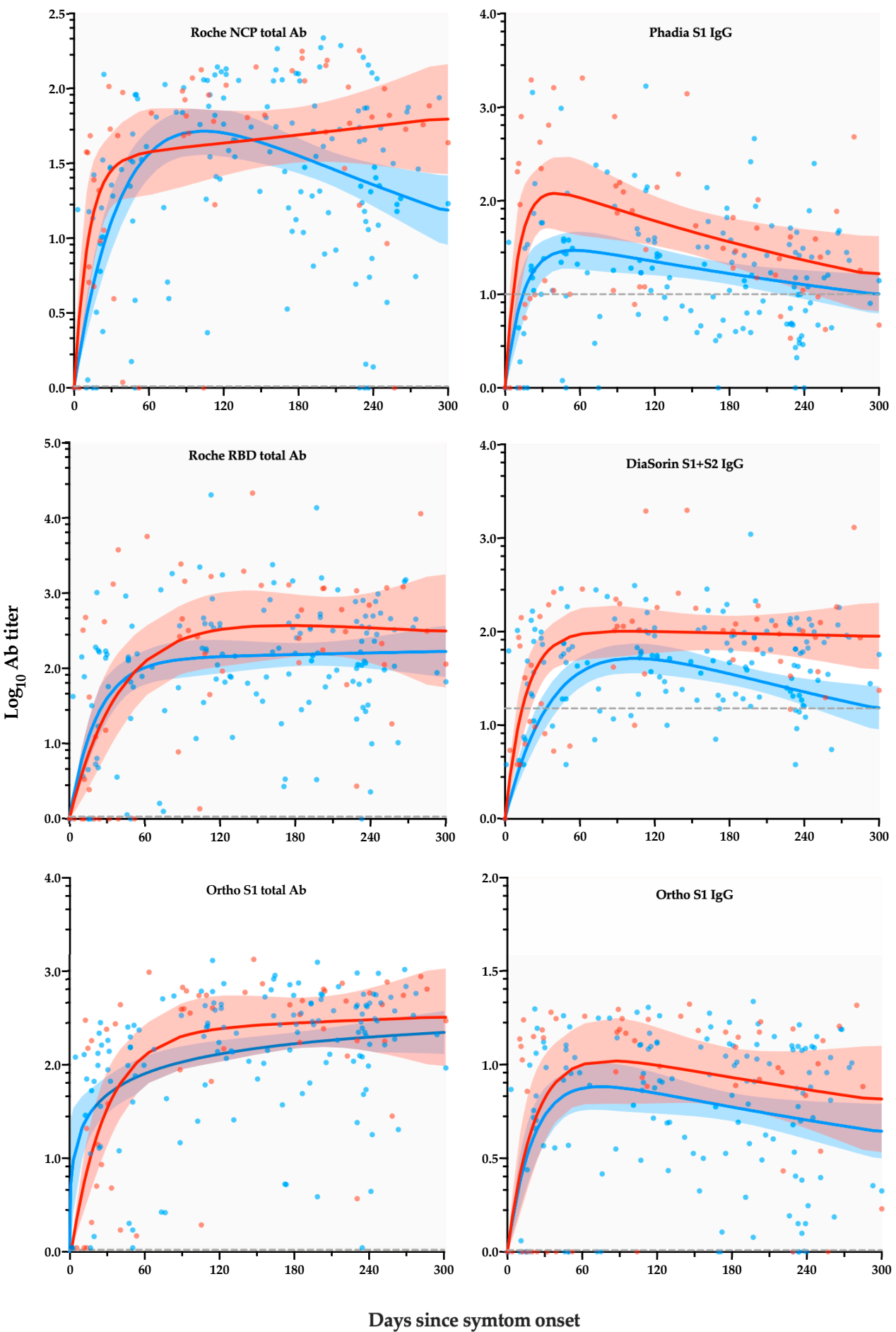

Figure 1. Level of antibody response by days after symptom onset according to severity. Depending on the assay and/or the population considered, a rapid increase in antibody titers was observed followed by a plateau phase or a decrease phase. Blue curves (and 95\% CI) and points represent non-hospitalized patients. Red curves (and 95\% CI) and points represent hospitalized patients. The dotted grey line corresponds to the manufacturer's cut-off for positivity.

The $\mathrm{C}_{\max }$ was consistently higher in hospitalized than in non-hospitalized patients (Table 3). 
Table 3. $\mathrm{T}_{\max }, \mathrm{C}_{\max }$ and time to plateau of the six assays subdivided into hospitalized and nonhospitalized patients. ${ }^{*}$ corresponds to the last time point assessed.

\begin{tabular}{|c|c|c|c|c|c|c|}
\hline \multirow{2}{*}{} & \multicolumn{3}{|c|}{ Hospitalized } & \multicolumn{3}{c|}{ Non-hospitalized } \\
\cline { 2 - 7 } & $\mathbf{T}_{\max }$ & $\mathbf{C}_{\max }$ & $\begin{array}{c}\text { Time to } \\
\text { plateau }\end{array}$ & $\mathbf{T}_{\max }$ & $\mathrm{C}_{\max }$ & $\begin{array}{c}\text { Time to } \\
\text { plateau }\end{array}$ \\
\hline Roche RBD total Ab (U/mL) & 180 & 363.1 & 140 & $300^{*}$ & 154.9 & 90 \\
\hline Roche NCP total Ab (COI) & $300^{*}$ & 64.6 & 285 & 102 & 50.1 & NA \\
\hline DiaSorin S1+S2 IgG (AU/mL) & 95 & 102.3 & 60 & 102 & 50.1 & NA \\
\hline Ortho S1 IgG (S/C) & 87 & 10.5 & NA & 75 & 7.4 & NA \\
\hline Ortho S1 total Ab (S/C) & $300^{*}$ & 331.1 & 150 & $300^{*}$ & 195.0 & 260 \\
\hline Phadia S1 IgG (U/mL) & 38 & 114.8 & NA & 55 & 28.8 & NA \\
\hline
\end{tabular}

Figure 2 represents the cumulative probability of positive samples after 14 days until the last follow-up point, i.e., 300 days. Of this selected cohort of 188 samples collected after the fourteenth day, 2, 8, 10, 21, 25 and 57 samples were reported as negative for the Ortho S1 total antibody, the Roche RBD total antibody, the Roche NCP total antibody, the Ortho S1 IgG, the DiaSorin S1 + S2 IgG and the Phadia S1 IgG, respectively. Assays targeting total antibodies, i.e., Ortho S1 total antibody, Roche RBD total antibody and Roche NCP total antibody, had the highest cumulative probability of positive samples at the latest follow-up period compared with IgG assays ( $p$ value $<0.0001$ ). The Ortho $\mathrm{S} 1$ total antibody assay was the only test that did not statistically differ from the $100 \%$ of cumulative positive probability, i.e., "all positive" on the figure at the latest follow-up point ( $p$ value $=0.1573$ ). The Phadia S1 IgG was the only test having a cumulative probability of positive samples below $50 \%$. The median survival was 239 days with this test.

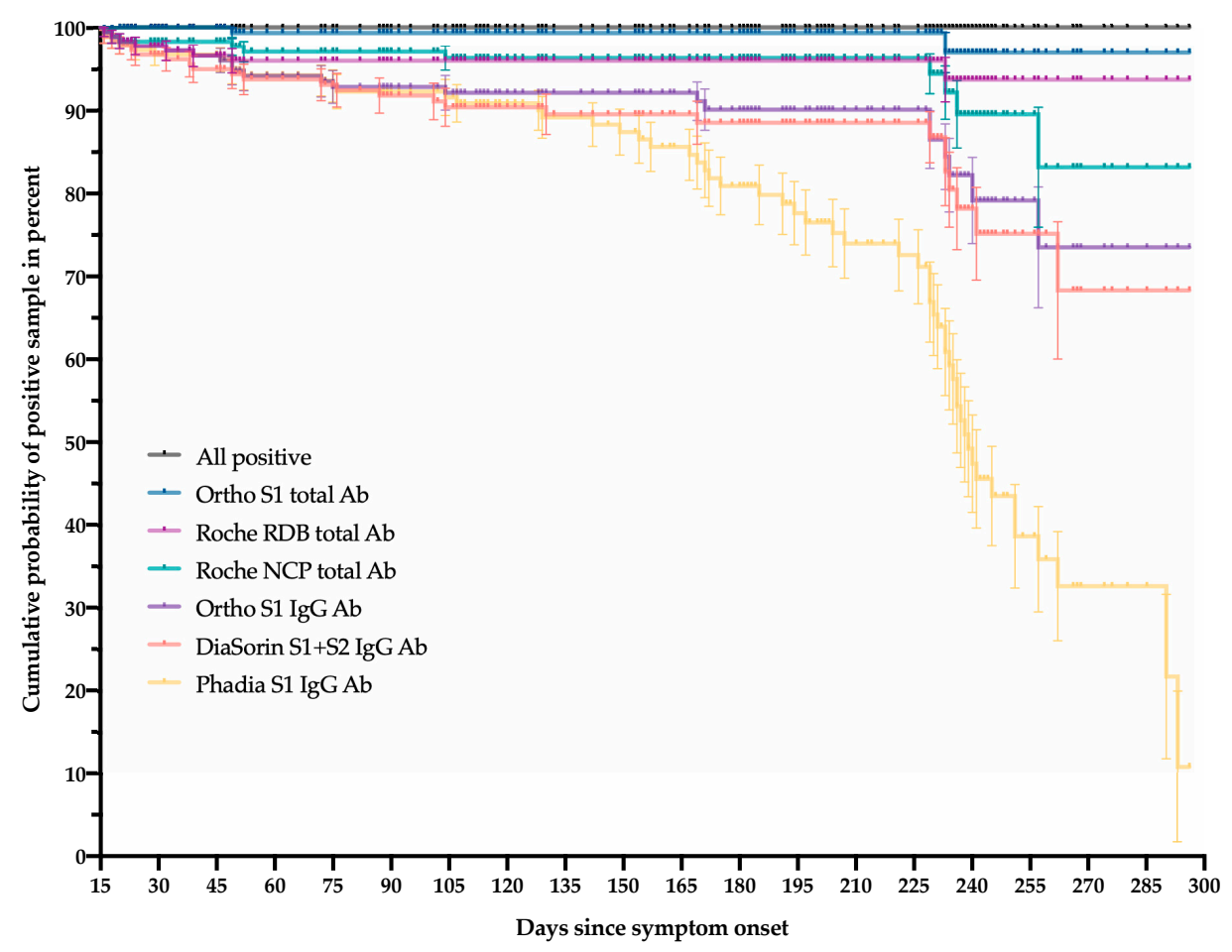

Figure 2. The cumulative probability of positive samples after 14 days until the last follow-up point, i.e., 300 days, using six different commercial assays. 
A comparison of the Mantel-Haenszel hazard ratios between the different tests is reported in Table 4 . Between the different assays, the Roche RBD total antibody and the Ortho S1 total antibody showed the highest agreement, Cohen's kappa index and correlation coefficient (Table 4). An agreement of at least $95 \%$ was only reached for total assays.

Table 4. Agreement (Agr.), Cohen's kappa index (k), correlation (r) and Mantel-Haenszel hazard ratios (M-H HR) between the different assays. Results in blue are statistically significant.

\begin{tabular}{|c|c|c|c|c|c|}
\hline & Roche NCP total Ab & DiaSorin S1+S2 IgG & Ortho S1 IgG & Ortho S1 total $\mathrm{Ab}$ & Phadia S1 IgG \\
\hline $\begin{array}{c}\text { Roche } \\
\text { RBD total } \\
\mathrm{Ab}\end{array}$ & $\begin{array}{l}\text { Agr. }=95.0 \% \\
\mathrm{k}=0.56(0.31-0.80) \\
\mathrm{r}=0.69(0.60-0.75) \\
\mathrm{M}-\mathrm{H} \text { HR }=0.80(0.32-2.02)\end{array}$ & $\begin{array}{l}\text { Agr. }=89.6 \% \\
\mathrm{k}=0.49(0.30-0.67) \\
\mathrm{r}=0.92(0.89-0.94) \\
\mathrm{M}-\mathrm{H} \text { HR }=0.35(0.18-0.70)\end{array}$ & $\begin{array}{l}\text { Agr. }=92.5 \% \\
\mathrm{k}=0.60(0.42-0.78) \\
\mathrm{r}=0.86(0.82-0.89) \\
\mathrm{M}-\mathrm{H} \mathrm{HR}=0.41(0.20-0.84)\end{array}$ & $\begin{array}{l}\text { Agr. }=97.0 \% \\
\mathrm{k}=0.69(0.45-0.92) \\
\mathrm{r}=0.92(0.90-0.94) \\
\mathrm{M}-\mathrm{H} \text { HR }=3.33(0.96-11.53)\end{array}$ & $\begin{array}{l}\text { Agr. }=72.1 \% \\
\mathrm{k}=0.20(0.08-0.31) \\
\mathrm{r}=0.76(0.69-0.81) \\
\mathrm{M}-\mathrm{H} \mathrm{HR}=0.22(0.14-0.36)\end{array}$ \\
\hline $\begin{array}{c}\text { Roche } \\
\text { NCP total } \\
\text { Ab }\end{array}$ & & $\begin{array}{l}\text { Agr. }=87.1 \% \\
\mathrm{k}=0.35(0.17-0.54) \\
\mathrm{r}-0.63(0.54-0.70) \\
\mathrm{M}-\mathrm{H} \text { HR }=0.42(0.22-0.82)\end{array}$ & $\begin{array}{l}\text { Agr. }=91.0 \% \\
\mathrm{k}=0.51(0.32-0.70) \\
\mathrm{r}-0.74(0.67-0.80) \\
\text { M-H HR }=0.49(0.25-0.99)\end{array}$ & $\begin{array}{l}\text { Agr. }=96.5 \% \\
\mathrm{k}=0.62(0.35-0.88) \\
\mathrm{r}-0.75(0.68-0.80) \\
\mathrm{M}-\mathrm{H} \text { HR }=3.81(1.23-11.82)\end{array}$ & $\begin{array}{l}\text { Agr. }=73.6 \% \\
\mathrm{k}=0.24(0.12-0.35) \\
\mathrm{r}-0.56(0.45-0.65) \\
\mathrm{M}-\mathrm{H} \text { HR }=0.24(0.15-0.39)\end{array}$ \\
\hline $\begin{array}{l}\text { DiaSorin } \\
\text { S1+S2 IgG }\end{array}$ & & & $\begin{array}{l}\text { Agr. }=90.1 \% \\
\mathrm{k}=0.61(0.45-0.76) \\
\mathrm{r}=0.80(0.74-0.84) \\
\mathrm{M}-\mathrm{H} \mathrm{HR}=1.19(0.67-2.13)\end{array}$ & $\begin{array}{l}\text { Agr. }=87.6 \% \\
\mathrm{k}=0.32(0.14-0.50) \\
\mathrm{r}=0.81(0.75-0.85) \\
\mathrm{M}-\mathrm{H} H \mathrm{HR}=5.52(2.60-11.76)\end{array}$ & $\begin{array}{l}\text { Agr. }=76.6 \% \\
\mathrm{k}=0.38(0.25-0.52) \\
\mathrm{r}=0.83(0.78-0.87) \\
\mathrm{M}-\mathrm{H} \text { HR }=0.46(0.30-0.70)\end{array}$ \\
\hline $\begin{array}{c}\text { Ortho S1 } \\
\text { IgG }\end{array}$ & & & & $\begin{array}{l}\text { Agr. }=89.6 \% \\
\mathrm{k}=0.37(0.17-0.56) \\
\mathrm{r}-0.91(0.88-0.93) \\
\mathrm{M}-\mathrm{H} H \mathrm{HR}=5.24(2.31-11.88)\end{array}$ & $\begin{array}{l}\text { Agr. }=78.6 \% \\
\mathrm{k}=0.43(0.30-0.56) \\
\mathrm{r}-0.77(0.71-0.82) \\
\mathrm{M}-\mathrm{H} \mathrm{HR}=0.39(0.25-0.62)\end{array}$ \\
\hline $\begin{array}{l}\text { Ortho S1 } \\
\text { total Ab }\end{array}$ & & & & & $\begin{array}{l}\text { Agr. }=71.1 \% \\
\mathrm{k}=0.14(0.05-0.24) \\
\mathrm{r}=0.66(0.57-0.73) \\
\mathrm{M}-\mathrm{H} \mathrm{HR}=0.15(0.09-0.26)\end{array}$ \\
\hline
\end{tabular}

\section{Discussion}

In this study, 201 sera samples from 84 RT-PCR confirmed COVID-19 patients with a 10-month follow-up period since symptom onset were included. Each patient's sample was analyzed on six commercial assays. As previously reported, the serological kinetics showed a high degree of heterogenicity that was patient-dependent but we also reported that these differences were also assay-dependent (Figure 1) [17,18]. The performance of these assays up to 15 days since symptom onset was particularly low because of the natural dynamics of the production of immunoglobulins $[2,7,8]$. Assays targeting total antibodies presented higher positivity rates and reached their highest positivity rates sooner than IgG assays. The inter-assay agreement was also higher between these total assays. The stratification by disease severity, expressed in this study by the patient's hospitalization status, showed a higher serological response in severe cases, which is consistent with previous observations [7,8,17,19-21]. The Phadia S1 IgG assay had a low performance to detect past SARS-CoV-2 infection compared with other assays. The manufacturer could probably consider redefining the cut-off, as has already been done for other assays, in order to improve the sensitivity [22-25]. However, in this study, only the cut-offs of the manufacturers were used so that there was no advantage for one method over another. Interestingly, the evaluation of the kinetic models demonstrated that assays targeting total antibodies consistently showed an increase of the antibody titer, at least in hospitalized patients (Figure 1, left panel). The same tendency was also observed in non-hospitalized patients except for the test that targeted antibodies directed against the NCP. On the other hand, assays targeting antibodies directed against the S1 subunit showed a slight decrease in antibody titers except for the DiaSorin S1 + S2 IgG in hospitalized patients (Figure 1, right panel). The drop in cumulative probability of positive samples was consistently highest for the Phadia S1 IgG compared with all other tests (Table 4). The Ortho S1 total antibody assay performed better than the Roche NCP total antibody assay but was not statistically different from the Roche RBD total antibody assay. The Roche RBD and NCP total antibody assays also performed better than all IgG assays. No statistically significant differences were observed between the DiaSorin S1 + S2 IgG and the Ortho S1 IgG (Table 4). 
Multiple studies have evaluated the long-term kinetics of anti-SARS CoV-2 antibodies using various assays. A sustained antibody response against the NCP antigen using the Roche NCP total antibody assay was found in several studies, i.e., between three and seven and a half months $[20,26,27]$. A maintained antibody response against the RBD antigen, as assessed by the Wantai and the Siemens total antibody assays, was also observed up to four months $[20,27]$. A decrease in anti-RDB IgG and anti-spike IgG levels was similarly observed over a period of up to five months in recent reports [28-30] and a significant decrease in sensitivity was also found in studies with up to five months of follow-up with the Abbott assay, which was directed against NCP IgG $[20,27,31]$. The YHLO assay, which detects both anti-NCP and anti-S IgG, showed high sensitivities from five weeks to three months after symptom onset [32]. Wajnberg et al. found stable antibody titers over a period of at least three months and only modest declines at the five-month time point [33].

In our study, the sustained antibody response as observed with total antibody assays (NCP and RBD) compared with IgG assays may be due to the additional response of nonIgG antibody isotypes. However, the reasons for the differences in assay performance over time for assays targeting the same antigen remain unclear [27]. The nature and structure of the target itself (for example, purified vs. recombinant, full-length vs. truncated, eukaryotic vs. prokaryotic expression system) as well as the protocol definition for determining the cut-off may, at least in part, affect the variability of inter-assays [7].

Whether the antibodies measured with commercial assays have a neutralizing capacity is paramount for indicating the potential level of protective immunity against SARS-CoV2 infection. Recently, Padoan et al. found that the Ortho S1 IgG $\left(R^{2}\right.$ adj $\left.=0.544\right)$ and DiaSorin S1 + S2 IgG $\left(\mathrm{R}^{2} \mathrm{adj}=0.402\right)$ assays were more correlated to neutralization activity compared with the Ortho S1 total antibody $\left(\mathrm{R}^{2} \mathrm{adj}=0.117\right)$ and Roche NCP total antibody $\left(\mathrm{R}^{2} \mathrm{adj}=0.046\right)$ assays [6]. The fact that anti-NCP assays showed a low correlation with the neutralizing capacity was expected as neutralizing antibodies are directed against the spike protein that is responsible for enabling the entry of the virus into the cells that express ACE-2 [22]. A strong correlation between the levels of anti-RBD or anti-spike antibodies and the neutralizing capacity has been found in several reports $[11,19,28,33,34]$. The neutralizing capacity was found to be maintained from one to five months $[19,30,35]$. However, although modest declines have been observed at three to five months [29,33], a few studies have pointed out a significant decrease of two to four-fold in neutralizing activity up to three months [21,27,36-38].

Data with a longer follow-up, i.e., $>6$ months, are however still sparse in the literature. Recently, Dan et al. found a slightly decreasing but stable antibody response (anti-S IgG, anti-RBD and anti-NCP using ELISAs) in a population of 188 COVID-19 patients, representing a total of 254 samples, with a maximal follow-up of eight months post-symptom onset. Forty-three samples were collected at $>6$ months after the initial infection [18]. Positivity rates at six to eight months were $90 \%$ (36/40 samples) for anti-S IgG, 88\% (35/40 samples) for anti-RBD IgG and 80\% (32/40 samples) for anti-NCP IgG. The positivity rate of patients with positive neutralizing antibodies was 90\% (36/40) [18]. In a population of 293 patients, Lau et al. also observed a trend towards lower antibody titers and neutralizing activity after seven months since illness onset but with a positivity rate of almost $100 \%$ after 30 days using an anti-RBD IgG ELISA assay [17]. A correlation of 0.53 was found between the ELISA assay and the neutralizing activity. They also found a stronger antibody response in severe patients compared with mildly-infected patients [23]. Ripperger et al. found that anti-RBD, anti-S2 and neutralizing antibodies remained detectable through five to seven months after illness [39].

In a population of 25 COVID-19 patients with a maximal follow-up of eight months, Hartley et al. observed that anti-NCP and anti-RBD IgG were found in each of the 24/25 and $25 / 25$ patients while neutralizing antibodies was detected in $22 / 25$ patients. They noted a decline in neutralization titers and antibody levels with time [14]. Nevertheless, they noted the persistence of SARS-CoV-2-specific B-memory cells, which could represent a more robust surrogate of long-lived humoral immune responses compared with antibodies [15]. 
It is important to remember that a few patients may develop specific antibodies but may not have detectable neutralizing antibodies. These are only correlation studies that are not related to direct measures of neutralizing activity [27]. The fact that neutralizing antibodies constitute a major protective mechanism against SARS-CoV-2 infection deserves further investigation $[17,27,33]$. A few differences between various neutralization assays, e.g., pseudo-particle neutralization, microneutralization, fluorescent focus reduction assays, microneutralization assays, plaque reduction neutralization tests, also exist with microneutralization tests found to be less sensitive than plaque reduction neutralization assays $[17,40]$.

The cellular measurements of the immune response have been proposed to be reliable markers for the maintenance of immunity following natural infection or vaccination [14,41,42]. Such approaches should be explored more. Even if previous exposure to SARS-CoV-2, either by true infection or by exposure to a vaccine, significantly decreases the risk of further positive RT-PCR tests [43-47], total immunity might not be guaranteed in all individuals because reinfection with SARS-CoV-2 exists [44-49].

Our study has a few limitations. We were not able to perform a neutralization assay at the time. The specificity of each assay was also not determined in this study including the cross-reactivity to common coronaviruses.

\section{Conclusions}

This study shows that assays are not equal for detecting past SARS-CoV-2 infection or investigating seroprevalence in samples for up to 10 months since symptom onset. Assays targeting the total antibody response have the highest positivity rates and perform better than tests targeting only IgG. The waning effect reported in several studies should be interpreted with caution because it may mostly depend on the assay considered. Even if previous exposure to SARS-CoV-2 decreases the risk of subsequent SARS-CoV-2 positivity, total immunity might not be guaranteed in all individuals. Further studies are required to correlate the seropositivity after such a long period post-infection with appropriate serological neutralization assays.

Author Contributions: Conceptualization, J.F., C.E. and J.D.; Data curation, J.F. and C.E.; Formal analysis, J.F., C.E. and J.D.; Investigation, J.F. and C.E.; Methodology, J.F., C.E., C.G. and J.D.; Resources, J.F., C.E. and M.E.; Software, J.F. and J.D.; Supervision, J.D.; Visualization, J.F. and J.D.; Writing — original draft, J.F.; Writing—review and editing, J.F., C.E., M.E., C.G., S.V.E., J.-M.D. and J.D. All authors have read and agreed to the published version of the manuscript.

Funding: This research received no external funding.

Institutional Review Board Statement: The study was conducted according to the guidelines of the Declaration of Helsinki, and approved by the Medical Ethical Committee of Saint-Luc Bouge (protocol code B0392020000005, 15 April 2020).

Informed Consent Statement: Patient consent was waived due to the retrospective design of this study.

Data Availability Statement: The data presented in this study are available on request from the corresponding author. The data are not publicly available due to ethical issues.

Acknowledgments: We thank the personnel of the Saint-Luc Bouge laboratory for technical assistance.

Conflicts of Interest: Among the authors, J.D. is CEO and founder of QUALIblood s.a., a contract research organization manufacturing the DP-Filter, is co-inventor of the DP-Filter (patent application number: PCT/ET2019/052903) and reports personal fees from Daiichi-Sankyo, Gedeon Richter, Mithra Pharmaceuticals, Stago, Roche and Roche Diagnostics outside the submitted work. The other authors have no conflict of interest to disclose. 


\section{References}

1. Butler-Laporte, G.; Lawandi, A.; Schiller, I.; Yao, M.; Dendukuri, N.; McDonald, E.G.; Lee, T.C. Comparison of Saliva and Nasopharyngeal Swab Nucleic Acid Amplification Testing for Detection of SARS-CoV-2: A Systematic Review and Meta-analysis. JAMA Intern. Med. 2021, 181, 353-360. [CrossRef]

2. Bohn, M.K.; Loh, T.P.; Wang, C.B.; Mueller, R.; Koch, D.; Sethi, S.; Rawlinson, W.D.; Clementi, M.; Erasmus, R.; Leportier, M.; et al. IFCC Interim Guidelines on Serological Testing of Antibodies against SARS-CoV-2. Clin. Chem. Lab. Med. 2020, 58, 2001-2008. [CrossRef] [PubMed]

3. Farnsworth, C.W.; Anderson, N.W. SARS-CoV-2 Serology: Much Hype, Little Data. Clin. Chem. 2020, 66, 875-877. [CrossRef] [PubMed]

4. Joyner, M.J.; Carter, R.E.; Senefeld, J.W.; Klassen, S.A.; Mills, J.R.; Johnson, P.W.; Theel, E.S.; Wiggins, C.C.; Bruno, K.A.; Klompas, A.M.; et al. Convalescent Plasma Antibody Levels and the Risk of Death from Covid-19. N. Engl. J. Med. 2021. [CrossRef]

5. Lippi, G.; Sciacovelli, L.; Trenti, T.; Plebani, M.; Executive Board of, S. Kinetics and biological characteristics of humoral response developing after SARS-CoV-2 infection: Implications for vaccination. Clin. Chem. Lab. Med. 2021. [CrossRef]

6. Padoan, A.; Bonfante, F.; Pagliari, M.; Bortolami, A.; Negrini, D.; Zuin, S.; Bozzato, D.; Cosma, C.; Sciacovelli, L.; Plebani, M. Analytical and clinical performances of five immunoassays for the detection of SARS-CoV-2 antibodies in comparison with neutralization activity. EBioMedicine 2020, 62, 103101. [CrossRef]

7. Favresse, J.; Brauner, J.; Bodart, N.; Vigneron, A.; Roisin, S.; Melchionda, S.; Douxfils, J.; Ocmant, A. An original multiplex method to assess five different SARS-CoV-2 antibodies. Clin. Chem. Lab. Med. 2020. [CrossRef]

8. Gillot, C.; Douxfils, J.; Cadrobbi, J.; Laffineur, K.; Dogne, J.M.; Elsen, M.; Eucher, C.; Melchionda, S.; Modaffarri, E.; Tre-Hardy, M.; et al. An Original ELISA-Based Multiplex Method for the Simultaneous Detection of 5 SARS-CoV-2 IgG Antibodies Directed against Different Antigens. J Clin Med 2020, 9, 3752. [CrossRef]

9. Lan, J.; Ge, J.; Yu, J.; Shan, S.; Zhou, H.; Fan, S.; Zhang, Q.; Shi, X.; Wang, Q.; Zhang, L.; et al. Structure of the SARS-CoV-2 spike receptor-binding domain bound to the ACE2 receptor. Nature 2020, 581, 215-220. [CrossRef] [PubMed]

10. Walls, A.C.; Park, Y.J.; Tortorici, M.A.; Wall, A.; McGuire, A.T.; Veesler, D. Structure, Function, and Antigenicity of the SARS-CoV-2 Spike Glycoprotein. Cell 2020, 181, 281-292. [CrossRef]

11. Ju, B.; Zhang, Q.; Ge, J.; Wang, R.; Sun, J.; Ge, X.; Yu, J.; Shan, S.; Zhou, B.; Song, S.; et al. Human neutralizing antibodies elicited by SARS-CoV-2 infection. Nature 2020, 584, 115-119. [CrossRef] [PubMed]

12. Patel, M.M.; Thornburg, N.J.; Stubblefield, W.B.; Talbot, H.K.; Coughlin, M.M.; Feldstein, L.R.; Self, W.H. Change in Antibodies to SARS-CoV-2 Over 60 Days Among Health Care Personnel in Nashville, Tennessee. JAMA 2020. [CrossRef] [PubMed]

13. Duysburgh, E.; Mortgat, L.; Barbezange, C.; Dierick, K.; Fischer, N.; Heyndrickx, L.; Hutse, V.; Thomas, I.; Van Gucht, S.; Vuylsteke, B.; et al. Persistence of IgG response to SARS-CoV-2. Lancet Infect. Dis. 2021, 21, 163-164. [CrossRef]

14. Hartley, G.E.; Edwards, E.S.J.; Aui, P.M.; Varese, N.; Stojanovic, S.; McMahon, J.; Peleg, A.Y.; Boo, I.; Drummer, H.E.; Hogarth, P.M.; et al. Rapid generation of durable B cell memory to SARS-CoV-2 spike and nucleocapsid proteins in COVID-19 and convalescence. Sci. Immunol. 2020, 5. [CrossRef]

15. Krammer, F.; Srivastava, K.; Simon, V. Robust spike antibody responses and increased reactogenicity in seropositive individuals after a single dose of SARS-CoV-2 mRNA vaccine. medRxiv 2021. [CrossRef]

16. World Health Organization. COVID-19 Weekly Epidemiological Update-31 January 2021. Available online: https:/ /www.who. int/publications/m/item/weekly-epidemiological-update (accessed on 2 February 2021).

17. Lau, E.H.Y.; Tsang, O.T.Y.; Hui, D.S.C.; Kwan, M.Y.W.; Chan, W.H.; Chiu, S.S.; Ko, R.L.W.; Chan, K.H.; Cheng, S.M.S.; Perera, R.; et al. Neutralizing antibody titres in SARS-CoV-2 infections. Nat. Commun. 2021, 12, 63. [CrossRef] [PubMed]

18. Dan, J.M.; Mateus, J.; Kato, Y.; Hastie, K.M.; Yu, E.D.; Faliti, C.E.; Grifoni, A.; Ramirez, S.I.; Haupt, S.; Frazier, A.; et al. Immunological memory to SARS-CoV-2 assessed for up to 8 months after infection. Science 2021, 371, eabf4063. [CrossRef]

19. Figueiredo-Campos, P.; Blankenhaus, B.; Mota, C.; Gomes, A.; Serrano, M.; Ariotti, S.; Costa, C.; Nunes-Cabaco, H.; Mendes, A.M.; Gaspar, P.; et al. Seroprevalence of anti-SARS-CoV-2 antibodies in COVID-19 patients and healthy volunteers up to 6 months post disease onset. Eur. J. Immunol. 2020, 50, 2025-2040. [CrossRef]

20. Gudbjartsson, D.F.; Norddahl, G.L.; Melsted, P.; Gunnarsdottir, K.; Holm, H.; Eythorsson, E.; Arnthorsson, A.O.; Helgason, D.; Bjarnadottir, K.; Ingvarsson, R.F.; et al. Humoral Immune Response to SARS-CoV-2 in Iceland. N. Engl. J. Med. 2020, 383, 1724-1734. [CrossRef]

21. Seow, J.; Graham, C.; Merrick, B.; Acors, S.; Pickering, S.; Steel, K.J.A.; Hemmings, O.; O’Byrne, A.; Kouphou, N.; Galao, R.P.; et al. Longitudinal observation and decline of neutralizing antibody responses in the three months following SARS-CoV-2 infection in humans. Nat. Microbiol. 2020, 5, 1598-1607. [CrossRef]

22. Favresse, J.; Cadrobbi, J.; Eucher, C.; Elsen, M.; Laffineur, K.; Dogne, J.M.; Douxfils, J. Clinical performance of three fully automated anti-SARS-CoV-2 immunoassays targeting the nucleocapsid or spike proteins. J. Med. Virol. 2021, 93, 2262-2269. [CrossRef]

23. Favresse, J.; Eucher, C.; Elsen, M.; Tre-Hardy, M.; Dogne, J.M.; Douxfils, J. Clinical Performance of the Elecsys Electrochemiluminescent Immunoassay for the Detection of SARS-CoV-2 Total Antibodies. Clin. Chem. 2020, 66, 1104-1106. [CrossRef]

24. Tre-Hardy, M.; Blairon, L.; Wilmet, A.; Beukinga, I.; Malonne, H.; Dogne, J.M.; Douxfils, J. The role of serology for COVID-19 control: Population, kinetics and test performance do matter. J. Infect. 2020, 81, e91-e92. [CrossRef] [PubMed] 
25. Tre-Hardy, M.; Wilmet, A.; Beukinga, I.; Favresse, J.; Dogne, J.M.; Douxfils, J.; Blairon, L. Analytical and clinical validation of an ELISA for specific SARS-CoV-2 IgG, IgA, and IgM antibodies. J. Med. Virol. 2021, 93, 803-811. [CrossRef] [PubMed]

26. Favresse, J.; Elsen, M.; Eucher, C.; Laffineur, K.; Van Eeckhoudt, S.; Nicolas, J.B.; Gillot, C.; Dogne, J.M.; Douxfils, J. Long-term kinetics of anti-SARS-CoV-2 antibodies in a cohort of 197 hospitalized and non-hospitalized COVID-19 patients. Clin. Chem. Lab. Med. 2020. [CrossRef] [PubMed]

27. Muecksch, F.; Wise, H.; Batchelor, B.; Squires, M.; Semple, E.; Richardson, C.; McGuire, J.; Clearly, S.; Furrie, E.; Greig, N.; et al. Longitudinal Serological Analysis and Neutralizing Antibody Levels in Coronavirus Disease 2019 Convalescent Patients. J. Infect. Dis. 2021, 223, 389-398. [CrossRef]

28. Ibarrondo, F.J.; Fulcher, J.A.; Goodman-Meza, D.; Elliott, J.; Hofmann, C.; Hausner, M.A.; Ferbas, K.G.; Tobin, N.H.; Aldrovandi, G.M.; Yang, O.O. Rapid Decay of Anti-SARS-CoV-2 Antibodies in Persons with Mild Covid-19. N. Engl. J. Med. 2020, 383, 1085-1087. [CrossRef]

29. Isho, B.; Abe, K.T.; Zuo, M.; Jamal, A.J.; Rathod, B.; Wang, J.H.; Li, Z.; Chao, G.; Rojas, O.L.; Bang, Y.M.; et al. Persistence of serum and saliva antibody responses to SARS-CoV-2 spike antigens in COVID-19 patients. Sci. Immunol. 2020, 5. [CrossRef]

30. Iyer, A.S.; Jones, F.K.; Nodoushani, A.; Kelly, M.; Becker, M.; Slater, D.; Mills, R.; Teng, E.; Kamruzzaman, M.; Garcia-Beltran, W.F.; et al. Persistence and decay of human antibody responses to the receptor binding domain of SARS-CoV-2 spike protein in COVID-19 patients. Sci. Immunol. 2020, 5, eabe0367. [CrossRef]

31. Sun, B.; Feng, Y.; Mo, X.; Zheng, P.; Wang, Q.; Li, P.; Peng, P.; Liu, X.; Chen, Z.; Huang, H.; et al. Kinetics of SARS-CoV-2 specific IgM and IgG responses in COVID-19 patients. Emerg. Microbes Infect. 2020, 9, 940-948. [CrossRef]

32. Li, K.; Huang, B.; Wu, M.; Zhong, A.; Li, L.; Cai, Y.; Wang, Z.; Wu, L.; Zhu, M.; Li, J.; et al. Dynamic changes in anti-SARS-CoV-2 antibodies during SARS-CoV-2 infection and recovery from COVID-19. Nat. Commun. 2020, 11, 6044. [CrossRef]

33. Wajnberg, A.; Amanat, F.; Firpo, A.; Altman, D.R.; Bailey, M.J.; Mansour, M.; McMahon, M.; Meade, P.; Mendu, D.R.; Muellers, K.; et al. Robust neutralizing antibodies to SARS-CoV-2 infection persist for months. Science 2020, 370, 1227-1230. [CrossRef]

34. Premkumar, L.; Segovia-Chumbez, B.; Jadi, R.; Martinez, D.R.; Raut, R.; Markmann, A.; Cornaby, C.; Bartelt, L.; Weiss, S.; Park, Y.; et al. The receptor binding domain of the viral spike protein is an immunodominant and highly specific target of antibodies in SARS-CoV-2 patients. Sci. Immunol. 2020, 5. [CrossRef]

35. Brigger, D.; Horn, M.P.; Pennington, L.F.; Powell, A.E.; Siegrist, D.; Weber, B.; Engler, O.; Piezzi, V.; Damonti, L.; Iseli, P.; et al. Accuracy of serological testing for SARS-CoV-2 antibodies: First results of a large mixed-method evaluation study. Allergy 2021, 76, 853-865. [CrossRef]

36. Crawford, K.H.D.; Dingens, A.S.; Eguia, R.; Wolf, C.R.; Wilcox, N.; Logue, J.K.; Shuey, K.; Casto, A.M.; Fiala, B.; Wrenn, S.; et al. Dynamics of Neutralizing Antibody Titers in the Months After Severe Acute Respiratory Syndrome Coronavirus 2 Infection. J. Infect. Dis. 2021, 223, 197-205. [CrossRef]

37. Prevost, J.; Gasser, R.; Beaudoin-Bussieres, G.; Richard, J.; Duerr, R.; Laumaea, A.; Anand, S.P.; Goyette, G.; Benlarbi, M.; Ding, S.; et al. Cross-Sectional Evaluation of Humoral Responses against SARS-CoV-2 Spike. Cell Rep. Med. 2020, 1, 100126. [CrossRef]

38. Wang, K.; Long, Q.X.; Deng, H.J.; Hu, J.; Gao, Q.Z.; Zhang, G.J.; He, C.L.; Huang, L.Y.; Hu, J.L.; Chen, J.; et al. Longitudinal dynamics of the neutralizing antibody response to SARS-CoV-2 infection. Clin. Infect. Dis. 2020. [CrossRef]

39. Ripperger, T.J.; Uhrlaub, J.L.; Watanabe, M.; Wong, R.; Castaneda, Y.; Pizzato, H.A.; Thompson, M.R.; Bradshaw, C.; Weinkauf, C.C.; Bime, C.; et al. Orthogonal SARS-CoV-2 Serological Assays Enable Surveillance of Low-Prevalence Communities and Reveal Durable Humoral Immunity. Immunity 2020, 53, 925-933. [CrossRef]

40. Riepler, L.; Rossler, A.; Falch, A.; Volland, A.; Borena, W.; von Laer, D.; Kimpel, J. Comparison of Four SARS-CoV-2 Neutralization Assays. Vaccines 2020, 9, 13. [CrossRef]

41. Rodda, L.B.; Netland, J.; Shehata, L.; Pruner, K.B.; Morawski, P.A.; Thouvenel, C.D.; Takehara, K.K.; Eggenberger, J.; Hemann, E.A.; Waterman, H.R.; et al. Functional SARS-CoV-2-Specific Immune Memory Persists after Mild COVID-19. Cell 2021, 184, 169-183. [CrossRef]

42. Sokal, A.; Chappert, P.; Barba-Spaeth, G.; Roeser, A.; Fourati, S.; Azzaoui, I.; Vandenberghe, A.; Fernandez, I.; Meola, A.; BouvierAlias, M.; et al. Maturation and persistence of the anti-SARS-CoV-2 memory B cell response. Cell 2021, 184, 1201-1213.e14. [CrossRef]

43. Lumley, S.F.; Wei, J.; O’Donnell, D.; Stoesser, N.E.; Matthews, P.C.; Howarth, A.; Hatch, S.B.; Marsden, B.D.; Cox, S.; James, T.; et al. The duration, dynamics and determinants of SARS-CoV-2 antibody responses in individual healthcare workers. Clin. Infect. Dis. 2021. [CrossRef]

44. Baden, L.R.; El Sahly, H.M.; Essink, B.; Kotloff, K.; Frey, S.; Novak, R.; Diemert, D.; Spector, S.A.; Rouphael, N.; Creech, C.B.; et al. Efficacy and Safety of the mRNA-1273 SARS-CoV-2 Vaccine. N. Engl. J. Med. 2021, 384, 403-416. [CrossRef]

45. Polack, F.P.; Thomas, S.J.; Kitchin, N.; Absalon, J.; Gurtman, A.; Lockhart, S.; Perez, J.L.; Perez Marc, G.; Moreira, E.D.; Zerbini, C.; et al. Safety and Efficacy of the BNT162b2 mRNA Covid-19 Vaccine. N. Engl. J. Med. 2020, 383, 2603-2615. [CrossRef]

46. Voysey, M.; Clemens, S.A.C.; Madhi, S.A.; Weckx, L.Y.; Folegatti, P.M.; Aley, P.K.; Angus, B.; Baillie, V.L.; Barnabas, S.L.; Bhorat, Q.E.; et al. Safety and efficacy of the ChAdOx1 nCoV-19 vaccine (AZD1222) against SARS-CoV-2: An interim analysis of four randomised controlled trials in Brazil, South Africa, and the UK. Lancet 2021, 397, 99-111. [CrossRef] 
47. Logunov, D.Y.; Dolzhikova, I.V.; Shcheblyakov, D.V.; Tukhvatulin, A.I.; Zubkova, O.V.; Dzharullaeva, A.S.; Kovyrshina, A.V.; Lubenets, N.L.; Grousova, D.M.; Erokhova, A.S.; et al. Safety and efficacy of an rAd26 and rAd5 vector-based heterologous prime-boost COVID-19 vaccine: An interim analysis of a randomised controlled phase 3 trial in Russia. Lancet 2021, 397, 671-681. [CrossRef]

48. To, K.K.; Tsang, O.T.; Leung, W.S.; Tam, A.R.; Wu, T.C.; Lung, D.C.; Yip, C.C.; Cai, J.P.; Chan, J.M.; Chik, T.S.; et al. Temporal profiles of viral load in posterior oropharyngeal saliva samples and serum antibody responses during infection by SARS-CoV-2: An observational cohort study. Lancet Infect. Dis. 2020, 20, 565-574. [CrossRef]

49. Tillett, R.L.; Sevinsky, J.R.; Hartley, P.D.; Kerwin, H.; Crawford, N.; Gorzalski, A.; Laverdure, C.; Verma, S.C.; Rossetto, C.C.; Jackson, D.; et al. Genomic evidence for reinfection with SARS-CoV-2: A case study. Lancet Infect. Dis. 2021, 21, 52-58. [CrossRef] 